\title{
The effects of personality traits and other variables on the specialty choices of resident doctors
}

\author{
Nalan Akis a, P. Eylul Taneri b, Guliz Avsar Baldan c, Aysegul Aydin d \\ a MD., Uludag University Faculty of Medicine, Public Health Dept. Görükle, Bursa \\ b MD., Uludag University Faculty of Medicine, Public Health Dept. Görükle, Bursa \\ c MD., Uludag University Faculty of Medicine, Public Health Dept. Görükle, Bursa \\ d MD., Uludag University Faculty of Medicine, Public Health Dept. Görükle, Bursa
}

\begin{abstract}
Objective: We aimed to evaluate the association between specialty choices and personality traits and other possible factors amongst resident doctors in Bursa, Turkey. Method: This crosssectional study involved 237 resident doctors who had been placed at the Medical Specialization Examination (MSE) between 2014-1015. The data was collected with the application of a questionnaire comprised of 33 questions and the Ten-Item Personality Inventory (TIPI). Student's $\mathrm{t}$ tests and Mann-Whitney U tests were used for the analysis of continuous variables, while chi-square tests were used for categorical variables. Results: We reached $76.8 \%(n=182)$ of the target population. Among the participants, 93.4\% reported that they would have been willing to participate in specialized training when they were senior medical students. Current specialization was the first choice in the exam for $57.4 \%$ of the participants. Top three reasons for choosing the current specialty were interest, working conditions and score at MSE. Sex, compulsory service participation and MSE scores were the variables that significantly affected internal/surgical specialty choices. After conducting the analysis for the top five specialties, internal medicine residents were found to be less open to new experiences $(p=0.021)$. Conclusion: It has been shown that sex, compulsory service participation and MSE scores primarily affect internal/surgical specialty choices. Additionally, internal medicine residents' personalities were less open to experiences. We believe that our results can be a guide for future studies.
\end{abstract}

Key words: Medical education, personality, specialization

Corresponding Author: P. Eylul Taneri, Uludag University Faculty of Medicine, Public Health Dept. Görükle/Bursa, Phone: +902242954281, Gsm: +90 5325926171 E-mail: eyltnr@gmail.com

Note: This research was accepted as a poster presentation in 19th Turkish National Public Health Congress (15-17 March 2017)

Copyright holder Turkish Journal of Public Health

This work is licensed under a Creative Commons Attribution-NonCommercial 4.0 International License. $(\mathrm{cc})$ EY-No This is an open Access article which can be used if cited properly. 


\title{
Araştırma görevlisi doktorların uzmanlık branş seçimine kişilik özellikleri ve diğer değişkenlerin etkileri
}

\begin{abstract}
Özet
Amaç: Bu çalışmadaki amacımız araştırma görevlisi doktorların uzmanlık seçimleri ile kişilik özellikleri ve diğer değişkenler arasındaki ilişkiyi değerlendirmektir. Yöntem: Kesitsel tipte yapılan çalışmaya 2014-2015 yıllarında Tıpta Uzmanlık Sınavı (TUS) ile yerleşmiş olan 237 araştırma görevlisi dahil edilmiştir. Veri 33 soru ve On-Maddeli Kişilik Ölçeği'ni içeren anket formu ile toplanmıştır. Sürekli veriler için Student's t ve Mann Whitney U testi, kategorik veriler için ki-kare testi kullanılmıştır. Bulgular: Hedef popülasyonun \%76.8'ine (n=182) ulaşılmıştır. Katılımcların \%93.4'ü son sınıf öğrencisi iken uzmanlık eğitimi almak istediklerini bildirmiştir. Uzmanlık eğitimi aldığı branş katılımcıların \%57.4'ünün ilk tercihi olarak saptanmıştır. Mevcut uzmanlık branşını tercih etmede en sık belirtilen nedenler konuya ilgi duyma, çalışma şartları ve TUS puanlarıdır. Dahili ve cerrahi bölüm seçiminde etkili olan değişkenler cinsiyet, zorunlu hizmete gitmek ve TUS puanıdır. En sık katılımcı barındıran beş branş için kişilik analizleri yapıldığında, dahiliye eğitimi alanların anlamlı olarak daha az 'deneyime açık' oldukları saptanmıştır ( $p=0.021)$. Sonuç: Cinsiyet, zorunlu hizmete gitme ve TUS puanı dahili ve cerrahi bölüm seçiminde etkili olan değişkenlerdir. Ek olarak dahiliye branşında eğitim alanlarda 'deneyime açıklık' daha az oranda saptanmıştır. Bu bulguların gelecekte yapılacak çalışmalara yol gösterici olacağı düşünülmektedir.
\end{abstract}

Anahtar kelimeler: Tıp eğitimi, kişilik, uzmanlık

\section{Introduction}

The decision process of training in a specific subject for the rest of their lives has a critical importance to physicians, and the wrong choice may create unfavorable effects on their lives. Previously, it has been shown that 1 of 4 Turkish resident doctors would have changed their specialty if they had a chance. ${ }^{1}$ This statistic accounted for $41 \%$ of the residents at a university in Turkey. ${ }^{2}$

There are modifiable or nonmodifiable factors that can affect the pathway of the choice of specialty. Some non-modifiable factors include age, total work years and gender, and some modifiable factors include lifestyle, intellectual challenge and private practice opportunities. $^{3}$

In Turkey, studies have shown that the main factors that affect specialty preference are personal skills, personal traits, working conditions, career opportunities, income satisfaction, work and private life balance, public opinion about the specialty and professors' attitudes.4-7

Personality traits found associated with career choice many times. ${ }^{8,9}$ Personality trait phenotypes have been classified differently by many scientists throughout the years. One of the leading models among them is Big-Five model of personality. This model briefly described by Goldberg with this sentences: 10 
"Factor I (Surgency or Extraversion) contrasts such traits as talkativeness, assertiveness and activity level with traits such as silence, passivity and reserve; Factor II (Agreeableness or Pleasantness) contrasts traits such as kindness, trust and warmth with such traits as hostility, selfishness, and distrust; Factor III (Conscientiousness or Dependability) contrasts such traits as organization, thoroughness, and reliability with traits such as carelessness, negligence, and unreliability; Factor IV (Emotional Stability vs. Neuroticism) includes such traits as nervousness, moodiness, and temperamentality; and Factor $V$ (whether labeled as Intellect or Openness to Experience) contrasts such traits as imagination, curiosity, and creativity with traits such as shallowness and imperceptiveness."

On the ground of the fact that there's very few study about the association between personality traits and medical specialty choices, we decided to conduct a research in that topic. The aim of the study to evaluate the association between specialty choices and personality traits and to determine other factors that could affect the specialty preference process of resident doctors in public, Turkey.

\section{Method}

We conducted a cross-sectional study that involved 237 resident doctors that had been placed at the Medical Specialization Examination (MSE) between 2014-1015. Among them, 144 were working in the Uludag University Medicine Faculty Hospital (UUMFH), while 93 were working in the Bursa Higher Specialization Training and Research Hospital (BHSTRH).

In Turkey, anesthetics, general surgery, pathology, urology, obstetrics and gynecology, neurosurgery, pediatric surgery, thoracic surgery, ophthalmology, cardiovascular surgery, otorhinolaryngology, plastic surgery, and orthopedic surgery are considered surgical specialties; emergency medicine, forensic medicine, family medicine, child psychiatry, paediatry, dermatology, infectious diseases and clinical microbiology, physical medicine and rehabilitation, respiratory medicine, public health, internal medicine, cardiology, neurology, nuclear medicine, radiation oncology, radiology, psychiatry, sports medicine, pharmacology, and genetics are considered internal specialties; and anatomy, biophysics, biostatistics, physiology, histology and embryology, medical biology, biochemistry, medical microbiology, medical history and bioethics are considered basic medicine specialties. In our study, we had so few people who worked in basic medicine specialties that we excluded them from the analyses.

After graduation Turkish doctors have to attend compulsory service. There's six areas that determined by Ministry of Health with considering State Planning Organization's development index of city/provinces (from 1 -the most developedto 6 -least developed-).

The data were collected under the supervision of 3 research assistants using questionnaires that contained 33 questions and the Ten-Item Personality Inventory (TIPI). Data were collected at SeptemberDecember 2016.

The Ten-Item Personality Inventory (TIPI) is a 10 -item measure of the Big-Five personality dimensions model. ${ }^{11}$ This inventory can be used for determining personality traits when personality is not the primary subject of the study. The validity and reliability of this instrument in the Turkish language were evaluated previously by Atak et al..12 This inventory measures the five most important personality traits: openness to experiences, agreeableness, emotional stability, conscientiousness and extraversion. Inventory items are formed by 7-point Likert scales. There is two items for each personaliy trait, and average of this two items has to be calculated. Some items are reverse scored $(2,4,6,8$, \& 10). No cut-off point is present and individuals' highest scored item is accepted as their personality trait.

The dependent variable of the study was specialty choice; the independent variables included age, gender, institution, marital status, maternal education, paternal education, family socioeconomic status, 
graduation year, compulsory service participation, compulsory service areas and institutions, specialization choice as a medical student, attrition from any specialty training and the reasons why, reasons for choosing the specialty and institutions and personality traits.

This study was approved by the Uludag University Institutional Ethics Board (26.07.2016, 2016-14/9), and all permissions were granted from the Uludag University Medicine Faculty and the Bursa Public Hospitals General Secretary.

IBM SPSS version 23.0 (IBM Corp., Armonk, USA) was used for the statistical analysis. Statistical significance was set at $\mathrm{p}<0.05$. Shapiro-Wilk tests were used for normality tests. Student's t tests and MannWhitney U tests were used for continuous variables, while chi-square tests were used for categorical variables.

\section{Results}

We reached 197 (83.1\%) resident doctor. Eight people (3.4\%) were on a long-term leave of absence (birth, disease, etc.), and 32 people $(13.5 \%)$ refused to participate.

After those didn't notify their specialty and three people who study in basic medicine excluded, 182 participants (76.8\% of study population) were added to our analysis.

The mean age of participants was $27.3 \pm 1.9$, and $54.4 \%(n=99)$ were female. There were 65 participants who were married (35.7\%). The sociodemographic properties of participants are shown in Table 1.

In total, $62.6 \% \quad(n=114)$ of the participants were working at UUMFH, and $37.4 \%(n=68)$ were working at BHSTRH. Of the participants, $61.5 \% \quad(n=112)$ were training in internal specialties. Participants' mean MSE score was $60.4 \pm 5.6$.

Among the participants, $41.7 \%$ $(n=76)$ graduated before 2014, and $93.4 \%$ $(\mathrm{n}=170)$ reported that they would have been willing to participate in specialized training when they were senior medical students. When they were senior medical students,
$37.6 \% \quad(n=64)$ considered to choose a specialty in surgical medicine. The top 5 most considered specialties were internal medicine $(n=21,12.4 \%)$, obstetrics and gynecology $(n=16,9.4 \%)$, psychiatry $(n=12$, $7.1 \%)$, paediatry $(\mathrm{n}=11,6.5 \%)$ and cardiology $(n=10,5.9 \%)$. Their $43.6 \%(n=74)$ started training in the specialty that he/she wished at medical school.

A total of $84.1 \% \quad(n=153)$ of the participants reported that they participated in compulsory service. Among those who completed compulsory service, $35.7 \%$ $(n=51)$ worked at the 5th-6th service areas. A total of $46.4 \% \quad(n=71)$ specified that performing compulsory service may have affected their choice of specialty.

Current specialization wasn't the first specialization training for $13.7 \%(n=25)$ of the participants. Specialties with the most attrition were as follows: emergency medicine $(n=4,16.0 \%)$ and internal medicine $(n=4,16.0 \%)$, followed by neurology $(n=3$, $12.0 \%)$ and paediatry $(n=3,12.0 \%)$. The most reported reasons were; heavy work load $(n=13,52.0 \%)$ and finding specialty not self- appropriate $(n=5,20.0 \%)$.

Current specialization was the first choice in exam for $57.4 \%(n=101)$ of the participants. Table 2 shows their reasons for choosing their current specializations.

Surgical specialty choices were significantly higher in male participants, the ones who didn't participate the compulsory service and the ones who had 60 or less points from MSE (respectively $\mathrm{p}=0.032$, $\mathrm{p}=0.021$ and $\mathrm{p}=0.008$ ) (Table 3 ).

There was no significant association between personality traits and internal/surgical specialty choice or prior attrition from any specialties ( $p>0.05)$. After conducting the analysis for the five specialties that had more participants (internal medicine, paediatry, family medicine, obstetrics and gynecology and anesthetics), internal medicine residents were found to be less open to experiences (Mann Whitney $\mathrm{U}=1328.0000, \mathrm{z}=-2.307$, $\mathrm{p}=0.021$ ) (Table 4). 
Table 1. Sociodemographic properties of the participants

\begin{tabular}{lcc}
\hline Properties & No (n) & Percentage (\%) \\
\hline Maternal education* & & \\
$\quad$ Illiterate/Literate & 16 & 8.9 \\
Primary school graduate & 55 & 30.3 \\
Secondary school graduate & 19 & 10.5 \\
High school graduate & 45 & 24.9 \\
University graduate & 46 & 25.4 \\
& & \\
\hline Paternal education * & & 1.7 \\
$\quad$ Illiterate/Literate & 3 & 13.8 \\
$\quad$ Primary school graduate & 25 & 8.8 \\
$\quad$ Secondary school graduate & 16 & 26.0 \\
$\quad$ High school graduate & 47 & 49.7 \\
$\quad$ University graduate & 90 & \\
$\quad$ & & 39.8 \\
\hline Family's economic status* & & 51.9 \\
$\quad$ Very good/Good & 72 & 8.3 \\
$\quad$ Moderate & 94 & 100.0 \\
\hline Bad/Very bad & 15 & \\
\hline Total & & \\
\hline
\end{tabular}

*1 missing answer

Table 2. Reasons of the participant' choose of current specialty (top five reasons)

\begin{tabular}{lcc}
\hline Reasons & Numbers (n) & Percentage (\%) \\
\hline Interest & 70 & 38.4 \\
Working conditions & 31 & 17.0 \\
Score at MSE & 21 & 11.5 \\
Career oppurtunity & 13 & 7.1 \\
Child patient & 10 & 5.5 \\
\hline
\end{tabular}


Table 3. Associations between specialty choices and some variables

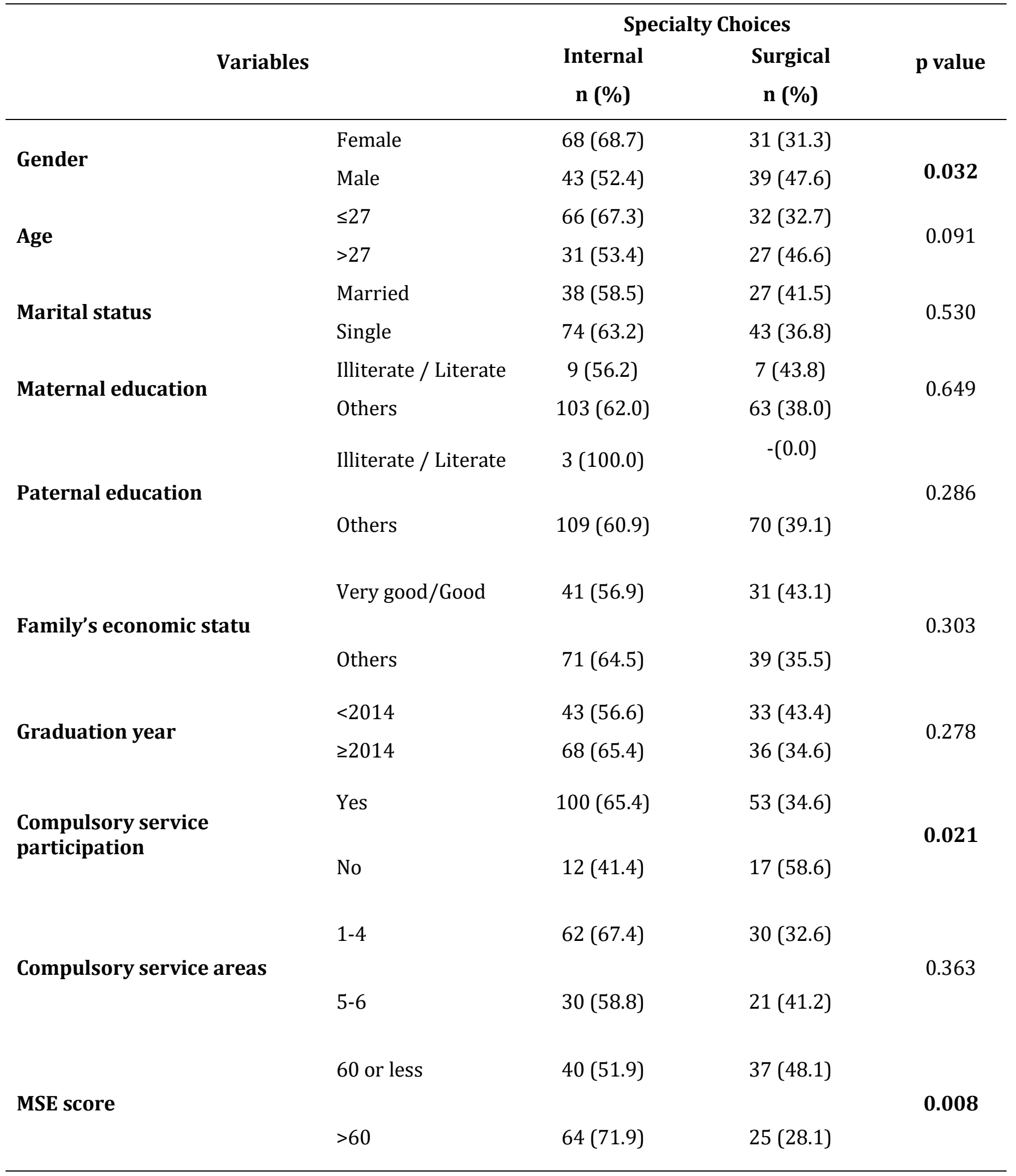


Table 4. Ten-Item Personality Inventory mean score comparison of the specialties that have the most participans

Ten-Item Personality Inventory score means \pm SD (medians)

\begin{tabular}{lllll}
\cline { 2 - 3 } Extraversion & Agreeableness & Conscientiousness & $\begin{array}{l}\text { Emotional } \\
\text { stability }\end{array}$ & $\begin{array}{l}\text { Opennes to } \\
\text { experiences }\end{array}$
\end{tabular}

\begin{tabular}{|c|c|c|c|c|c|c|}
\hline $\begin{array}{l}\text { Internal } \\
\text { specialties }\end{array}$ & $\begin{array}{c}11 \\
2\end{array}$ & $\begin{array}{c}5.34 \pm 1.35 \\
(5.50)\end{array}$ & $\begin{array}{c}5.08 \pm 1.01 \\
(5.00)\end{array}$ & $\begin{array}{c}5.86 \pm 1.18 \\
(6.00)\end{array}$ & $\begin{array}{c}4.43 \pm 1.46 \\
(4.50)\end{array}$ & $\begin{array}{c}4.43 \pm 1.28 \\
(4.50)\end{array}$ \\
\hline snecialties & & $4.99 \pm 1.60$ & $5.06 \pm 1.12$ & $5.75 \pm 1.03$ & $4.44 \pm 1.39$ & $4.73 \pm 1.49$ \\
\hline & 70 & $(5.00)$ & $(5.00)$ & $(6.00)$ & $(4.50)$ & $(5.00)$ \\
\hline & 27 & $5.38 \pm 1.30$ & $5.34 \pm 0.98$ & $5.88 \pm 1.48$ & $4.66 \pm 1.59$ & $4.00 \pm 1.21^{*}$ \\
\hline medicine & & $(5.50)$ & $(5.50)$ & $(6.50)$ & $(4.50)$ & $(4.00)$ \\
\hline Others & 15 & $5.17 \pm 1.48$ & $5.03 \pm 1.07$ & $5.81 \pm 1.06$ & $4.39 \pm 1.41$ & $4.64 \pm 1.38$ \\
\hline & 5 & $(5.50)$ & $(5.00)$ & $(6.00)$ & $(4.50)$ & $(4.50)$ \\
\hline Paediatry & 25 & $4.97 \pm 1.33$ & $5.04 \pm 1.03$ & $5.45 \pm 1.14$ & $4.00 \pm 1.54$ & $4.32 \pm 1.23$ \\
\hline & & (5.50) & $(5.00)$ & $(5.50)$ & $(4.00)$ & $(4.00)$ \\
\hline Otherc & 15 & $5.24 \pm 1.48$ & $5.08 \pm 1.07$ & $5.88 \pm 1.11$ & $4.50 \pm 1.41$ & $4.59 \pm 1.39$ \\
\hline 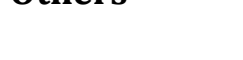 & 7 & $(5.50)$ & $(5.00)$ & $(6.00)$ & $(4.50)$ & $(4.50)$ \\
\hline & 13 & $5.62 \pm 1.22$ & $5.29 \pm 1.25$ & $5.87 \pm 0.82$ & $4.45 \pm 1.28$ & $4.70 \pm 0.81$ \\
\hline Family & & $(6.00)$ & $(5.25)$ & $(6.00)$ & $(4.50)$ & $(5.00)$ \\
\hline Others & 16 & $5.17 \pm 1.47$ & $5.06 \pm 1.05$ & $5.82 \pm 1.14$ & $4.43 \pm 1.45$ & $4.54 \pm 1.41$ \\
\hline & 9 & $(5.50)$ & $(5.00)$ & $(6.00)$ & $(4.50)$ & $(4.50)$ \\
\hline & 22 & $5.19 \pm 1.60$ & $5.19 \pm 0.95$ & $5.66 \pm 1.20$ & $4.11 \pm 1.18$ & $4.97 \pm 1.53$ \\
\hline $\begin{array}{l}\text { Obstetrics } \\
\text { \&Gvnecologv }\end{array}$ & & $(5.00)$ & $(5.00)$ & $(6.00)$ & $(4.00)$ & $(5.50)$ \\
\hline Others & 16 & $5.21 \pm 1.45$ & $5.06 \pm 1.07$ & $5.84 \pm 1.11$ & $4.48 \pm 1.46$ & $4.49 \pm 1.35$ \\
\hline & 0 & $(5.50)$ & $(5.00)$ & $(6.00)$ & $(4.50)$ & $(4.50)$ \\
\hline Anaesthetics & 14 & $4.61 \pm 1.37$ & $4.57 \pm 1.05$ & $5.61 \pm 0.71$ & $4.92 \pm 1.38$ & $4.61 \pm 1.54$ \\
\hline & & $(4.00)$ & $(4.50)$ & $(5.50)$ & $(4.50)$ & $(5.00)$ \\
\hline Others & 16 & $5.25 \pm 1.46$ & $5.011 \pm 1.05$ & $5.84 \pm 1.15$ & $4.40 \pm 1.44$ & $4.55 \pm 1.37$ \\
\hline & 8 & (5.50) & $(5.00)$ & $(6.00)$ & $(4.50)$ & $(4.50)$ \\
\hline
\end{tabular}

${ }^{*} \mathrm{p}<0.05$ 


\section{Discussion}

Our study showed that over half of the participants were training in a specialty that they had selected as their first choice on their MSE. The most reported reasons to choose a specialty were as follows: interest, working conditions, MSE score, career opportunities and pediatric patients. Three reasons, interest, working conditions and career opportunities, are consistent with both local and foreign literature, but none of the participants stated a satisfying income in response to the question "Why did you chose this specialty?", despite being a common reason in the literature. $3-5,7,13,14$

Earlier studies showed that gender is an important factor for specialty preference. ${ }^{3,14-18}$ It is known that men are more likely to choose surgical specialties.5,15,19 In accordance with the literature, we found that women were more likely to prefer internal specialties. This could be a result of the role that assigned by society to women; but this prediction and the other possible factors should be evaluated in future studies.

The specialties with the highest attrition rates were emergency medicine and internal medicine. The most common reason for leaving a specialty was a heavy workload. Turkey is the only country that has more emergency room visits than the population of the country; therefore, the high frequency of emergency medicine attrition is not surprising. ${ }^{20}$ Even if the participants did not report an assault, it is a fact that the emergency room is the most common place where violence against doctors occurs, which could also be a reason for quitting. ${ }^{21}$ The Turkish Internal Medicine Specialty Society reported that internal medicine specialists examine 100 patients/day at policlinics and 500 patients/day during shifts. ${ }^{22}$ If we include the extra work of being a resident in the process of training, the high frequency of internal medicine attrition becomes more meaningful.

More than half of the participants who performed compulsory service specified that engaging in compulsory service would not affect their specialty choice; however, in our analysis, we determined that those who attend compulsory service were more likely to chose internal specialties. This situation may be caused by closely experiencing challenges that surgeons face in the field, such as malpractice or violence.

In some studies, the personality traits of the surgeons have been found to be more exhibitive, commanding, extraverted, responsible and emotionally stable. 23-26 However, in our study, we were not able to find any relationship between surgical/nonsurgical specialty choice and personality traits.

When we conducted the analysis for the five specialties that have the most participants we found that only internal medicine residents had a lower openness to experiences. In a prospective study, it has been found that the medical students with higher emotional stability scores were more likely to prefer internal medicine and the ones with the higher openness to experience scores were more likely to prefer psychiatry. ${ }^{27}$ These diversities may base on the fact that our study and the mentioned study utilized different personal trait inventories. For this reason, it'd be more useful if future studies can be conducted with a consistent inventory choice.

The strength of this study is to involve both resident doctors who work at University and Research \&Training hospitals. Thus we could see the preferance choices of the bothside of the specialization education. Also our study has some limitations. We only included resident doctors that had been placed at the 2014-2015 MSE and this limited us to a specific time range. Additionally for the reason that the inventory we used was a brief form to assess Big-Five personality dimensions model, it may has caused some errors during the personality evaluation process next to providing practicability.

In conclusion we found that women, those who participated compulsory service and those who had 60 points or more from MSE were more likely to chose internal specialties; and personality traits were not significantly associated with internal/surgical specialty choice. Also interest, working conditions and MSE scores 
were the top reasons for choosing the current specialty. Additionally, we determined that the personality traits of internal medicine residents showed that they were less open to experiences. Unfortunately we weren't able to find significant personality trait differences for each and every specialty that can enlighten the preference process. But, we believe our results are important for the future studies in the field of medical education. Because specialty training plays a substantial role in health care services, future studies that include the entire country must be conducted to improve specialty training programs.

\section{Conflicts of Interest}

The authors confirm that they have no conflict of interest.

\section{Author contributions}

Akış N: Study conception and design, drafting of manuscript, critical revision

Taneri PE: Study conception and design, acquisition of data, analysis and interpretation of data, drafting of manuscript

Avsar Baldan G: acquisition of data, analysis and interpretation of data, drafting of manuscript

Aydin A: acquisition of data, analysis and interpretation of data, drafting of manuscript

\section{References}

1. Sayek İ, Aktan AÖ, Demir T, Özyurt A. Medical Specialty Training Report. Ankara: Turkish Medical Association Publication, 2015.

2. Çeler A, Kara İH, Baltacı D, Çeler H. Investigation of the Relationship of Job Satisfaction and Depression Level among Medical Faculty Research Assistants. Konuralp Medical Journal 2015;7(3):125133.

3. Ibrahim M, Fanshawe A, Patel V et al. What factors influence British medical students' career intentions? Medical teacher 2014; 36:1064-72.

4. Tan MN, Özçakar N, Kartal M. Resident Doctors' Professional Satisfaction and Its Effect on Their Lives. Marmara Medical Journal 2012;25:20-5.

5. Tekin Ç, Güneş G, Türkol E. Residency Choices of Medical Students at Inonu University Medical Faculty and the Factors to Affect These Choices. İnönü Üniversitesi Sağlık Bilimleri Dergisi 2013; 1: 5-10.

6. Yatangac FB. Personality characteristics as a prognostic factor for specialty choice in nursing and medical students. Adana: Çukurova University; Master Thesis, 2010.

7. Kalaça S, Gürpınar MA, Yeğen B, Anak $S$, Dağlı T. Specialty Field and Instutition Choosing Reasons of Senior Medical Students at Istanbul. 15 $5^{\text {th }}$ Medical Specialization Training Meeting. İzmir; 2009.

8. Judge TA, Heller D, Mount MK. Fivefactor model of personality and job satisfaction: a meta-analysis. The Journal of applied psychology 2002; 87:530-41.

9. Barrick MR, Mount MK. The Big 5 Personality Dimensions and JobPerformance - a Metaanalysis. Pers Psychol 1991; 44:1-26.

10. Goldberg LR. The Structure of Phenotypic Personality-Traits. Am Psychol 1993; 48:26-34.

11. Gosling SD, Rentfrow PJ, Swann WB. $A$ very brief measure of the Big-Five personality domains. J Res Pers 2003; 37:504-28.

12. Atak $\mathrm{H}$. The Turkish Adaptation of the Ten-Item Personality Inventory. Archives of Neuropsychiatry 2013; 50:312-9.

13. Takeda Y, Morio K, Snell L, Otaki J, Takahashi M, Kai I. Characteristic profiles among students and junior doctors with specific career preferences. BMC Medical Education 2013; 13:125.

14. Heikkila TJ, Hyppolo $\mathrm{H}$, Vanska J, Halila H, Kujala S, Virjo I et al. What predicts doctors' satisfaction with their chosen medical specialty? A Finnish national study. BMC Medical Education 2016; 16:125.

15. Buddeberg-Fischer B, Klaghofer R, Abel T, Buddeberg C. Swiss residents' speciality choices--impact of gender, personality traits, career motivation and life 
goals. BMC Health Services Research 2006; 6:137.

16. Gjerberg E. Medical women -towards full integration? An analysis of the specialty choices made by two cohorts of Norwegian doctors. Social Science \& Medicine 2001; 52:331-43.

17. Shrestha B, Pokhrel YR, Butterworth K. Determinants of Postgraduate Students' Choices of Speciality. J Nepal Med Assoc 2016; 54:1-7.

18. Kassamali R, Gill C, Murphy A, Cheetham L, Ali F. Finding direction: what influences medical students in their final career speciality choices? Medical Teacher 2013; 35:4, 339-339.

19. Lambert TW, Goldacre MJ, Turner G. Career choices of United Kingdom medical graduates of 2002: questionnaire survey. Medical Education 2006; 40:514-21.

20. Pala K. Health-care reform in Turkey: far from perfect. Lancet 2014; 383:28.

21. Adaş E, Elbek O, Bakır K. Report on Violence in the Health Sector. Turkish Medical Association Gaziantep-Kilis Chamber of Medicine. 2013.

22. Turkish Internal Medicine Specialty Society. Internal Medicine Specialty Training. Available at: http://www.tihud.org.tr/main/content?ref= 2\&child=180. Accessed November 9, 2017.

23. Fang J-T, Lii S-C. Relationship between personality traits and choosing a medical specialty. Journal of the Formosan Medical Association 2015; 114:1116-21.

24. Sievert M, Zwir I, Cloninger KM, Lester N, Rozsa S, Cloninger CR. The influence of temperament and character profiles on specialty choice and well-being in medical residents. PeerJ 2016; 4:e2319.

25. Rotge JY, Lemogne C, Jouvent R, Fossati P. Relationship between personality dimensions and medical specialty in 1661 residents. J Psychosom Res 2015; 79:331-2.

26. Hoffman BM, Coons MJ, Kuo PC. Personality differences between surgery residents, nonsurgery residents, and medical students. Surgery 2010; 148:187-93.
27. Markert RJ, Rodenhauser P, ElBaghdadi MM, Juskaite K, Hillel AT, Maron BA. Personality as a prognostic factor for specialty choice: a prospective study of 4 medical school classes. Medscape journal of medicine. 2008; 10:49 